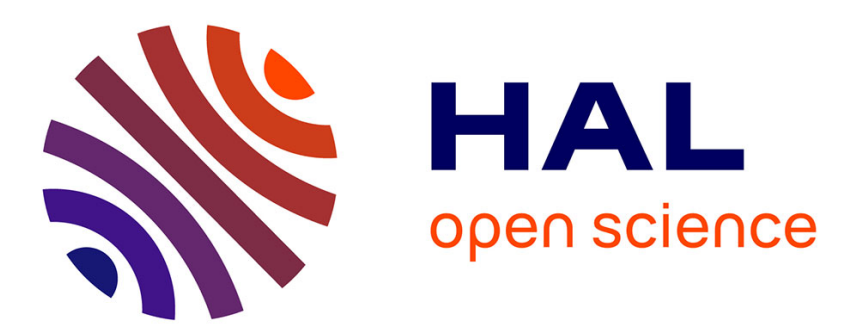

\title{
The cost of equity and exchange listing evidence from the French stock market
}

\author{
Michel Dubois, Cem Ertur
}

\section{To cite this version:}

Michel Dubois, Cem Ertur. The cost of equity and exchange listing evidence from the French stock market. [Research Report] Laboratoire d'analyse et de techniques économiques(LATEC). 1997, 28 p., ref. bib. : 2 p. hal-01527157

\section{HAL Id: hal-01527157 \\ https://hal.science/hal-01527157}

Submitted on 24 May 2017

HAL is a multi-disciplinary open access archive for the deposit and dissemination of scientific research documents, whether they are published or not. The documents may come from teaching and research institutions in France or abroad, or from public or private research centers.
L'archive ouverte pluridisciplinaire HAL, est destinée au dépôt et à la diffusion de documents scientifiques de niveau recherche, publiés ou non, émanant des établissements d'enseignement et de recherche français ou étrangers, des laboratoires publics ou privés. 


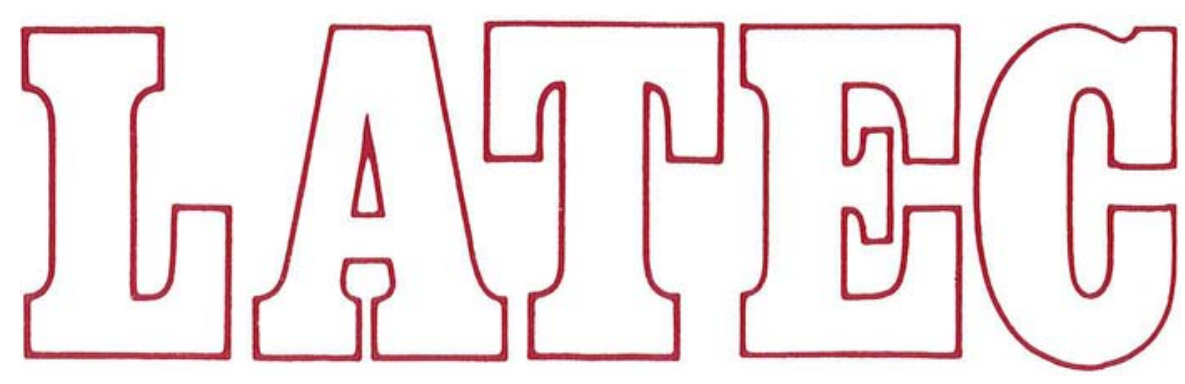

\section{LABORATOIRE D'ANALYSE ET DE TECHNIQUES ÉCONOMIQUES}

U.R.A. 342 C.N.R.S.

DOCUMENT de TRAVAIL

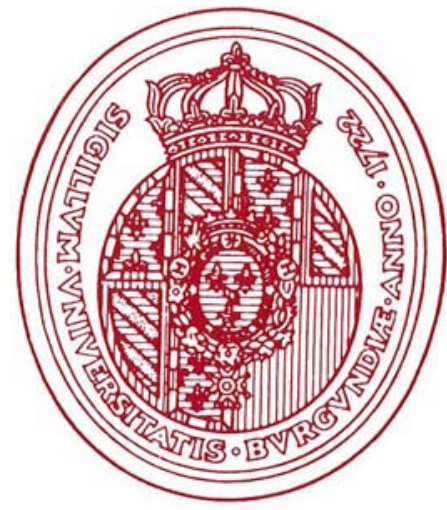

UNIVERSITE DE BOURGOGNE

FACULTE DE SCIENCE ECONOMIQUE ET DE GESTION

4, boulevard Gabriel - 21000 DIJON - Tél. 80395430 - Fax 80395648 
$\mathbf{n}^{\circ} 9710$

\title{
The Cost of Equity and Exchange Listing \\ Evidence from the French Stock Market
}

\author{
Michel DUBOIS ${ }^{1}$ and Cem ERTUR ${ }^{2}$
}

March 1997

First draft February 1996

This draft February 1997

\footnotetext{
' Université de Neuchâtel, Pierre-à-Mazel 7, 2000 Neuchâtel, Switzerland

E-mail: michel.dubois(a) $)$ seco.unine.ch

'LATEC. Université de Bourgogne, Pole d'Economie et de Gestion, 2 Bd Gabriel, 21000 Dijon, France.

E-mail: cem.ertur(a)satie.u-bourgogne.fr

Part of this research was completed when Cem Ertur was visiting researcher at "Centre de Recherche et Développement en Economique ». University of Montreal (fall 1996). He would like to thank C.R.D.E. and its director Pierre Perron for their hospitality.

We would like to thank seminar participants at the 1996 European Financial Management Meeting in Innsbruck (especially Yakov Amihud). Erasmus University at Rotterdam and the University of Geneva for their helpful comments and suggestions. Financial support from the Fonds National Suisse de la Recherche Scientifique (grant $n^{\circ} 12-40455.94$ ) is gratefully acknowledged.
} 


\begin{abstract}
:
We reconsider the behaviour of prices around the period close to the listing on the Marché $\dot{a}$ Règlement Mensuel (RM). First, an event study based on a sample of 60 firms has been set up to test the existence of the exchange listing effect on the French market. Then we discuss and test the financial reasons which can justify abnormal returns around the announcement day and the day of the listing. We explore four reasons to explain the impact of the stock exchange listings: one is the informative content of the operation which induces an upward revision of the future earnings. Three other hypotheses rely on a decrease in the discount rate originated by less risky cash flows, an increase in trading activity and/or, an increase in the relative size of the firm's investor base. We establish a relation between the abnormal returns and the changes in the parameters of the market model after listing on the $R M$. Cross-sectional regressions provide support for this model but the fact that the $R M$ is a forward market also matters. Trading activity seems to play an indirect role in explaining the abnormal returns. However, the model does not explain the price behaviour at the announcement of listing.
\end{abstract}

Key words : exchange listing, event study, abnormal returns

\title{
Résumé :
}

Nous examinons le comportement du prix des actions sur une période entourant la date de transfert sur le Marché à Règlement Mensuel (RM). Nous effectuons en premier lieu une étude d'événement sur un échantillon de 60 sociétés pour tester l'existence d'un effet de transfert sur le marché français. Nous discutons et testons ensuite les raisons financières qui peuvent justifier les rentabilités anormales détectées autour de la date d'annonce du transfert ainsi qu'autour de la date de transfert effectif. Nous proposons ainsi quatre explications de l'impact du transfert : la première repose sur le contenu informationnel de l'opération qui induit une révision à la hausse des bénéfices futurs. Trois autres hypothèses sont fondées sur la baisse du taux d'actualisation causée par des cash-flows moins risqués, une augmentation du volume des transactions et/ou une augmentation du nombre d'investisseurs détenant les titres en question. Nous établissons une relation entre les rentabilités anormales et la variation des paramètres du modèle de marché après le transfert sur le RM. Les résultats obtenus sur les régressions en coupe transversale confirment cette relation mais le fait que le RM soit un marché à terme joue également un rôle. Le volume des transactions semble aussi jouer un rôle indirect dans l'explication des rentabilités anormales. Toutefois, le modèle n'explique pas le comportement des prix à l'annonce du transfert.

Mots-clés : transferts sur le Règlement Mensuel, étude d'événement, rentabilités anormales 


\section{Introduction}

Recently, a number of studies have treated the importance of the stock market (or the listing on certain market segments) on the return of securities. These researches can be classified into three categories: the first one examines exchange listings in a national frame; the second one studies the influence of a double listing on both the national and the foreign markets ${ }^{3}$; finally, the third one observes the effect on stock prices of the inclusion in or the exclusion from an index ${ }^{4}$. The aim of these researches is to determine if listing on a more important stock market creates value by lowering the expected return of equity. Here, we are interested in the exchange listing of stocks from the Second Marché (hereafter SM market) or the Marché au Comptant (MC market) towards the Marché à Règlement Mensuel (RM market) in France. The previous studies underline a positive response of the market prices before listing. However, listing on a more active market results in price variations that are not yet totally explained.

In this research, we re-examine the behaviour of prices around the period close to the market switch, because Dubois [1993] highlighted a strong positive reaction of $+3.90 \%$ (statistically significant at $1 \%$ ) during the week before the listing on the $R M$ market. Poor post-listing stock returns of $-3.99 \%$ (significant at $1 \%$ ) were obtained for the first week in France. These results are not specific to the French stock market since Kadlec and Mac Connell [1994] reported similar figures when listing on the NYSE. The post-listing performance of stock returns was explored by Hwang and Jayaraman [1993] for stocks listing on the Tokyo Stock Exchange 1st section, and abnormal returns were also found to be negative after listing. In the US, this pattern persists over long periods of time (see Dharan and Ikenberry [1994]). In France however, the range of abnormal returns over short periods of time is much larger than observed elsewhere for comparable periods. The objective of this paper is twofold. First, we will analyse the effect of listing on a major market but within a different framework. Second, we will contribute to the growing literature concerned with the influence of market location on the cost of equity.

As the price of a stock is equal to the present value of the future cash flows, the revision of the current price is due to the revision of the expected cash flows or to a decrease in the discount rate. Based on the results of an event study, we explore four reasons to explain the impact of the stock exchange listings: one is the informative content of the operation which induces an upward revision of the future earnings. Three other hypotheses rely on a decrease in the discount rate originated by: (a) less risky cash flows, (b) an increase in trading activity and/or, (c) an increase in the relative size of the firm's investor base ${ }^{5}$.

\footnotetext{
${ }^{3}$ See Karolyi [1996] for a survey.

${ }^{4}$ Among others, see Harris and Gurel [1986], Schleifer [1986], Woolridge and Ghosh [1986], Jain [1987], Dhillon and Johnson [1991]. Beneish and Whaley [1995] and Lynch and Mendenhall [1995]. For a study relative to the French market, see Bancel and Vai [1994]. In any case, the inclusion in an index with Future traded contracts results in an abnormal rise of the return and the exclusion from results in a fall of the return.

${ }^{5}$ Other hypotheses are mentioned by Sanger and Mac Connell [1986].
} 
This paper is organised as follows: in section 2, we present the characteristics of the French stock market which are directly related to our purpose. The sample and the data sources are described and the methodology used to measure abnormal returns is presented (market model). In section 3, we examine the behaviour of financial analysts around the listing. More specifically, we test and reject the hypothesis of an upward revision of the expected earnings after listing. We examine the systematic risk before and after listing. In average and after accounting for non synchronous trading, our results do not support the hypothesis of an upward revision of the systematic risk. Recently, Brennan et al. [1996] have shown that firm characteristics such as dollar volume of share trading, analyst following, S\&P 500 membership, spread and twelve month lagged return determine the cross-section of security returns. As far as we are concerned, changes in the first two variables may help to explain why alphas decrease at the time of listing. In section 4 , we are concerned with liquidity before and after listing. As we will see it later (see section 2.1), the French market microstructure has changed deeply during the period studied. Because $M C$ and $S M$ were call markets before 1989, we focus on turnover and trading volumes. In section 5, the degree of investor recognition and the related hypothesis about neglected firms are tested. Merton's [1987] model is particularly well suited to analyse the relation between expected returns, the firm's investor base and short sales restrictions theoretically. However, the number of analysts following a firm do not increase strongly after listing. In section 6 , we show how abnormal returns around listing are related to the changes in the parameters of the market model. Cross-sectional regressions provide support for this model but the fact that the $R M$ is a forward market also matters. Section 7 concludes the paper.

\section{Market reactions on the French market}

\subsection{The exchange listing on the French stock market}

The French Stock Market has experienced major structural changes over the last fifteen years. A more detailed examination is required to understand its peculiarities. Because Solnik [1988], Barone [1990] and Huang and Stoll [1991] reviewed the major differences among international stock markets, we focus on those peculiarities which are directly related to this research.

Since February 1983, the French capital market has been composed of an Official List and a second-tier equity market called $S M$ market. Major stocks of the Official List are traded on a forward market, the $R M$ market and all trades within a month are settled at the end of that month. The remaining stocks are exchanged on a cash basis on the $M C$ market and the $S M$ market. Transactions take place on a unique market and there is no double listing in France ${ }^{6}$. The $R M$ market provides an institutional access to short selling to any investor. Whenever a short position or a long position is taken, a deposit varying from $20 \%$ (cash deposit) to $100 \%$ (stocks) of the position is required. At the end of the settlement period, the position may be

\footnotetext{
${ }^{6}$ However, before October $1983, R M$ stocks were listed on both the $R M$ and the $M C$ simultaneously.
} 
extended for the next period by borrowing money or stocks at a cost. None of these facilities is available for stocks listed on the $M C$ and the $S M$ markets.

After 1983, Initial Public Offerings of private firms were made on the $S M$ market, except for major international projects (Eurotunnel, Eurodisneyland, ...) and privatisations (1986-1987 and 1993-1994). Since that date, a proportion of $50 \%$ of the IPOs ${ }^{7}$ has been big enough to be listed immediately on the $R M$. However, in order to reduce the percentage of shares sold at the time of the IPO and the losses incurred by existing shareholders, these firms were listed first on the $S M$. To be listed on the $R M$ market, the following requirements must be completed: (a) at least $25 \%$ of the total number of shares must be publicly held (b) the market must be liquid enough (average daily trading volume bigger than FFR 1.5 million/day and frequency of trading) and (c) the market value must be higher than a required level. This level has increased from FFR 150 million in 1985 to FFR 1 billion in 1994. MC and SM firms having fulfilled these requirements may apply directly for listing on the $R M$. However, the marketing department of the Société des Bourses Françaises ${ }^{8}$ (SBF) may suggest the listing and outsiders do not know by whom the procedure was initiated. The securities which will switch are easy to forecast. The choice is made according to the precise criteria available to the investors. On the other hand, the time at which the listing is completed partly depends on the number of securities excluded from the $R M$.

Until June 1986, the procedure for trading equities on the Official List was a periodic call. From June 1986 to January 1991, the most liquid stocks of the whole market were progressively traded on a continuous computerised market named $C A C$ system. In January 1991, all the stocks were traded on the CAC. One year after (January 1992), the market was reorganised to accommodate transactions of less liquid stocks. Since then and independently of the market location, stocks are classified into three categories depending on the number of transactions per day. Continuous trading has been restricted to the first and the second group which are composed of the most liquid securities. The last major change consists in the elimination of fixed commissions on July, 1989. Since then, the structure of trading costs has been directly related to the order size and the Sociétés de Bourse (individual brokers) have offered competitive commission rates. However, one year after, the commissions were slightly higher for small trades ${ }^{9}$. To summarise, when listing on the $R M$ market, firms experience two major changes concerning: (a) short sale arrangements and levered positions and (b) settlement procedures.

\footnotetext{
${ }^{7} 50 \%$ of the IPOs had a market value up to FFR 500 million and $30 \%$ were higher than FFR 1,250 million (nominal currency unit). In France, IPO's are secondary offerings and at least $10 \%$ of the existing shares must be held publicly after listing (legal constrain). By the law, firms are not allowed to raise capital at the time of going public. In other words, the proceeds benefit those shareholders who sell the shares and not the firm.

${ }^{8}$ Compagnie des Agents de (hange before 1987.

${ }^{9}$ Before 1989 , the fees were proportional to the order size and equal to 1.13 percent (VAT included) up to FFR 0.6 million, Investir $(09 / 22 / 90$, p. 15$)$ report unchanged or higher trading costs up to 1.72 percent.
} 


\subsection{The sample}

In this section we describe the data used to estimate and test our hypothesis. The sample period is between January 1, 1985 and December 31, 1994. The stock prices were collected from the $A F F I$ data base for securities switching before June 30, 1991 and from Datastream ${ }^{10}$ for the period from July 1, 1991 to December 31, 1994. The event date is the day on which the firm is listed on the $R M$. An advice from the Commission des Opérations de Bourse $(C O B)$ is published before the listing. The announcement date is available from different sources ( $S B F$, Bulletin Officiel de la Bourse, Conseil des Bourses de Valeur) but most of the time, the COB was the first in publishing the information. In this study, the announcement date is considered to be the earliest date available from the above mentioned sources. The firms and the date of listing were obtained from L'Année Boursière and checked with the advice of the $C O B$. The number of days elapsing from the announcement day up to the listing day is highly variable from a minimum of two days to a maximum of seventy-seven days with a mean of nineteen days (median of fourteen days).

During that period (see table 1), 46 firms switched from the $M C$ and 40 from the $S M$ to the $R M$. However, 26 firms involved in mergers, take-over bids and seasoned equity issues during the period running from one month before to one month after the event were eliminated to avoid spurious results. The sample of « pure » exchange listings was restricted to firms listed on the Paris Bourse.

Table 1: Listing on the $R M$ 1985-1994

\begin{tabular}{|c|c|c|c|c|c|c|c|c|c|c|c|}
\hline Year & 85 & 86 & 87 & 88 & 89 & 90 & 91 & 92 & 93 & 94 & Total \\
\hline \multicolumn{12}{|c|}{ Total listing } \\
\hline $\mathrm{MC}$ & 11 & 7 & 6 & 1 & 7 & 6 & 3 & 2 & 1 & 2 & 46 \\
\hline SM & 1 & 2 & 3 & 5 & 10 & 5 & 3 & 2 & 3 & 6 & 40 \\
\hline $\begin{array}{l}\mathrm{MC}+\mathrm{SM} \\
\text { Sample }\end{array}$ & 12 & 9 & 9 & 6 & 17 & 11 & 6 & 4 & 4 & 8 & 86 \\
\hline $\mathrm{MC}$ & 7 & 3 & 3 & 0 & 3 & 6 & 2 & 2 & 1 & 1 & 28 \\
\hline SM & 1 & 0 & 3 & 3 & 9 & 4 & 3 & 1 & 3 & 5 & 32 \\
\hline $\mathrm{MC}+\mathrm{SM}$ & 8 & 3 & 6 & 3 & 12 & 10 & 5 & 3 & 4 & 6 & 60 \\
\hline
\end{tabular}

For nine (sixteen) $S M$ firms, the switching occurred during the first three (five) years after the IPO. In fact, as it was recently documented ${ }^{11}$, our results may be biased by the poor long-term performance of IPOs. To examine this possibility, the market excess return was computed for each firm. The holding period begins three years before the listing on the $R M$ and one month after the IPO. There is no evidence of systematic underperformance.

Surprisingly, $M C$ stocks are smaller than $S M$ stocks at the time of listing (see table 2). The reason is that most of the small stocks were listed at the beginning of the sample period. The dramatic increase in stock prices ( $128 \%$ on average during the sample period) renders the

\footnotetext{
${ }^{10}$ We thank the CEDIF (HEC-Lausanne) and in particular D. Isakov for the access to this data base.

"See Loughram and Ritter [1995] among other.
} 
comparison ineffective. However, when size is measured at the same point in time (12/31/1994), $M C$ stocks remain smaller than $S M$ stocks. The composition of the final sample is not altered when stocks are eliminated but the firm size increases slightly.

Table 2: Market value of firms switching to the $R M$ 1985-1994

\begin{tabular}{lcccc}
\hline $\begin{array}{l}\text { Market value in } \\
\text { million FFR }\end{array}$ & Min & Median & Mean & Max \\
\hline $\begin{array}{l}\text { Total listing }{ }^{a} \\
\text { SM }\end{array}$ & 590.4 & 3050.0 & 3734.0 & 11857 \\
MC & 154.3 & 2206.0 & 4308.4 & 28336 \\
Sample ${ }^{a}$ & & & & \\
SM & 682.4 & 3201.0 & 3598.6 & 10041.4 \\
MC & 181.3 & 3363.1 & 5359.0 & 28336 \\
Adjusted & & & & \\
SM & 976.5 & 3228.8 & 3921.4 & 14722.7 \\
MC & 413.9 & 3856.6 & 5637.9 & 24630.4 \\
\hline
\end{tabular}

${ }^{a}$ Values are considered at the time of listing and ${ }^{b}$ at the end of the sample period (12/31/1994).

Generally, the listing date coincides with the first day of the settlement period on the $R M$ (one month in France). Daily returns corrected for dividends and operations on capital are computed in the following way:

$$
R_{i, t}=100 \times \operatorname{Ln} \frac{P_{i, t}}{P_{i, t-1}}
$$

The period taken into account runs from two hundred and fifty days before the announcement to two hundred and fifty days after the listing.

\subsection{The methodology}

In order to estimate the effect of listing on firm's value, we conducted an event study around the announcement and the listing. Any pricing model may be used as forecasting model (benchmark). The deviation from the benchmark is defined as the difference between:

$$
\hat{u}_{i, t}=R_{i, t}-\hat{R}_{i, t}
$$

where $R_{i, t}$ is the return of security $i$ at time $t$, and $\hat{R}_{i, t}$ the return forecasted by the model, and $\hat{u}_{i, t}$ is the forecast error term.

The benchmark used here is the market model $(M M A R)$. The market-value weighted index used is the SBF $250^{12}$ index (or the ex SBF 240-index) essentially consisting of forward traded securities. This index is calculated with opening prices. To limit the bias due to nonsynchronous trading, we retained the opening prices to calculate the returns. The

\footnotetext{
${ }^{12}$ The choice of the index does not affect the range of abnormal returns, see Dubois [1993, p. 53].
} 
announcement date is considered to be the date at which the information was published (day zero). The listing date corresponds to the day when listing on the $R M$ is achieved. The abnormal returns are calculated in the interval $[-5 ;+5]$ and the parameters are estimated over $[-250 ;+250]$. Besides, the stocks in the index are traded on a forward market whereas the securities for which we have to estimate the $\beta$ must be paid cash during the period preceding the listing. Hamon and Jacquillat [1992, p.81] assess the settlement effect at $0.97 \%$ on individual data, which approximately corresponds to the cost of carry estimated at $0.86 \%$. Therefore, the returns have to be expressed on the same basis. In order to minimise the number of corrections, the returns of the market index before listing were transformed to obtain cash values $^{13}$.

Previous tests have shown that systematic risk does not change when switching to the NYSE (see Reints and Vandenberg [1975], Ying, Lewellen, Schlarbaum and Lease [1977], Fabozzi and Hershkoff [1979] and Prakash, Parhizgari and Perritt [1989]). However, one of the arguments that justify the listing on the $R M$ is the liquidity of the stock. The increase in trading volume is directly bound to the number of daily trades which, in turn, implies the possibility to obtain synchronous prices. Recently, Denis and Kadlec [1994] and Vihj [1994] emphasised the magnitude of the correction for non synchronous trading when measuring systematic risk around an event (Scholes and Williams [1977], Dimson [1979] and Fowler and Rorke [1983]). Nevertheless, there is no evidence that these models produce better forecasts when using real data (see Cowan and Sergeant [1996]). This empirical conjecture is examined more carefully in section 3.2. Because it is not clear if systematic risk (and residual variance) remains constant after listing, abnormal returns are estimated with the following model:

$\left\{\begin{array}{l}R_{i, t}=\alpha_{i}^{B}+\beta_{i}{ }^{B} R_{m, t}+\sum_{j=-5}^{-1} \gamma_{i, j}^{B} \delta_{i, t}+\varepsilon_{i, t} \quad \varepsilon_{i, t} \sim N\left(0, \sigma_{i}^{B}\right), t \in\{-T, \cdots,-1\}, i \in\{1, \cdots, N\} \\ \delta_{j, t}=1 \text { if } j=t \text { and } 0 \text { otherwise }\end{array}\right.$
$\left\{\begin{array}{l}R_{i, t}=\alpha_{i}^{A}+\beta_{i}{ }^{A} R_{m, t}+\sum_{j=0}^{+5} \gamma_{i, j}^{A} \delta_{i, t}+\varepsilon_{i, t} \quad \varepsilon_{i, t} \sim N\left(0, \sigma_{i}^{A}\right), t \in\{0, \cdots, T\}, i \in\{1, \cdots, N\} \\ \delta_{j, t}=1 \text { if } j=t \text { and } 0 \text { otherwise }\end{array}\right.$

The subscript $B(A)$ indicates that the parameters are estimated during the period before (after) the announcement. With this specification -two separate regressions- the parameters of the market model as well as the variances of the residuals before and after the event may be different. Dummy variables are used because this method is shown to be preferable to the one suggested by Patell [1976]. As underlined by Karafiath and Spencer [1991, p. 355] (hereafter $\mathrm{KS}$ ), the main advantage is that the prediction errors are obtained directly as coefficient estimates of the model. Moreover, this method accounts for covariances across the time series of abnormal returns at the firm level.

\footnotetext{
${ }^{13}$ See appendix A2. The short term interest rate on the FFR is the one month LIBOR.
} 
Simulations realised by Boehmer, Musumeci and Poulsen [1991] (hereafter BMP) show that when the event induces a variance variation ${ }^{14}$, Patell's method leads to reject the null hypothesis too often. Under these conditions, a test based on an ordinary cross-section performs better. This solution was used by Mac Connell and Sanger [1987]. However, a standardised cross-section outperforms these methods (see Boehmer et al. [1991]). The tests presented here are computed with both the KS's method and the BMP standardised crosssection method in order to take into account the variance effect.

\subsection{Empirical results}

Table 3 summarises the average abnormal return during the two weeks surrounding the announcement day and the listing day. Because the information is released after the market opening, we find a positive reaction of 0.79 (significant at 1\%) at the time +1 (and not at the announcement date). Before the announcement, the CARs are insignificant at the $5 \%$ level $(\mathrm{CAR}[-5 ;-1]=-0.10$ and $z$-stat $=0.21)$. Positive and significant at $5 \%$ CARs are obtained after the announcement $(\operatorname{CAR}[+1 ;+5]=1.58$ and $z$-stat $=2.15)$. The positive market reaction is in the line of the results obtained previously for other markets (see appendix 1).

Table 3: Abnormal return when listing on the RM

\begin{tabular}{ccccc|cccc}
\hline & \multicolumn{3}{c}{ Announcement } & \multicolumn{4}{c}{ Listing } \\
& AR & CAR & KS & BMP & AR & CAR & KS & BMP \\
\hline-5 & -0.20 & -0.20 & -0.76 & -0.66 & 0.05 & 0.05 & 0.40 & 0.38 \\
-4 & 0.22 & 0.03 & 1.00 & 1.16 & -0.16 & -0.11 & -0.33 & -0.36 \\
-3 & -0.00 & 0.02 & -0.09 & -0.10 & 0.32 & 0.21 & 1.46 & 1.49 \\
-2 & -0.16 & -0.14 & -0.87 & -0.92 & 0.62 & 0.83 & 2.27 & 2.01 \\
-1 & 0.04 & -0.10 & 0.31 & 0.31 & -0.02 & 0.82 & 0.07 & 0.08 \\
0 & 0.23 & 0.13 & 0.82 & 1.21 & 1.16 & 1.98 & 3.61 & 2.91 \\
1 & 0.79 & 0.92 & 2.55 & 3.51 & -0.07 & 1.91 & -0.42 & -0.36 \\
2 & 0.20 & 1.12 & 0.79 & 0.76 & -0.53 & 1.38 & -1.68 & -1.79 \\
3 & 0.01 & 1.14 & 0.25 & 0.23 & 0.04 & 1.42 & 0.28 & 0.31 \\
4 & 0.18 & 1.32 & 0.67 & 0.69 & -0.04 & 1.38 & 0.21 & 0.21 \\
5 & 0.15 & 1.48 & 1.20 & 1.43 & -0.61 & 0.78 & -1.92 & -2.13 \\
\hline
\end{tabular}

Values in bold italics (bold) are significant at $1 \%(5 \%)$ level.

This statistics becomes insignificant (1.87) at the $5 \%$ level when one stock is removed (October 1987). This outlier has a strong effect on variance when using BMP methodology but a limited impact on abnormal returns. The abnormal return at +5 is reduced to -0.48 and the CAR is 0.86 . Nevertheless, our conclusions are unaffected.

\footnotetext{
${ }^{14}$ The hypothesis that the event (split, earning release...) itself induces an increase in the variance is frequently verified (see for example Donders and Vorst [1996]).
} 
The abnormal returns at the announcement are insensitive to the way by which the $t$-test is constructed. Abnormal returns were also computed with the parameters of the market model being estimated before the announcement $[-250 ;-6]$, after the announcement $[+6 ; 250]$ and over the full period $[-250 ;-6] \cup[6 ; 250]$. All these procedures lead to minor differences that may be ignored.

Around the listing date, our results confirm an abnormal increase in the price of 1.16 (significant at $1 \%$ ) on the day of listing. We find also a positive and significant reaction at time -2 (0.62). Cumulated abnormal returns during the week before the event are positive and significant at $1 \%(\operatorname{CAR}[-5 ; 0]=1.98$ and $z$-stat $=3.13)$ but they are not significant at the $5 \%$ level during the week after listing $(\operatorname{CAR}[+1 ; 5]=-1.21$ and $z$-stat $=-1.91)$. These results contrast with those obtained by Dubois [1993] (3.99 and -3.20 for the week before and after listing) but are very close when aggregating the CAR for the two weeks surrounding the listing $(0.78 v s 0.79)$ and not significant at $5 \%(z$-stat $=0.91)$.

To summarise, a positive reaction at both the announcement and listing date is found. During the week after the announcement, CAR's are found to be positive and significant; however, they are negative and insignificant during the week after listing.

\section{The information effect}

\subsection{The revision of expected earnings}

Switching trading location leaves unaffected the fundamentals of the firm. Nevertheless, like many other financial operations, listing on a major Stock Exchange may convey information toward investors. Grammatikos and Papaioannou [1986, p. 487] mentioned that "The firm's application to the NYSE confirms the confidence of the firm's management that the firm has matured enough to uphold the continuous financial standards for listing ". Moreover, this confidence is ratified externally by Stock Market Authorities. These authors predict a differentiated announcement effect: the reaction should be nil for firms benefiting from favourable expectations, because they have no reason to be revised. On the other hand, the reaction should be positive for firms that were subject to rather unfavourable expectations up to then. Empirically, they classify firms as high performers or low performers based on the reciprocal of the coefficient of variation of the growth rate of quarterly earnings. As expected, the firms with the best performances do not react, whereas the others rise by $0.5 \%$ between the application and the approval, and again by $0.38 \%$ during the week after the listing. Although the excess returns are significant, they are low.

Furthermore, the event is not fully anticipated by the market. To demonstrate an informational effect, it is more appropriate to study how the earnings forecasts made by financial analysts are likely to be revised after the announcement. Indeed, if this operation conveys positive information about the firm, analysts must interpret it as a signal for a rise in the future earnings. 
In that case, we are entitled to expect a positive market reaction. On the other hand, the securities which have not been revised should not present any significant reaction to the listing. Besides, this hypothesis does not explain why the returns are abnormally positive at both the announcement and the listing date: in the best case, this is a partial explanation. However, to get an insight into this hypothesis we collected the earnings forecast available around the announcement and the exchange listing date. The most appropriate measure would be the long term earnings forecast. However, this information is provided by a very limited number of analysts ( 88 percent of the firms are followed by one analyst at the five years horizon). Because of data availability, we focused on the one year forecasts. Data are from IBES Europe History Tape. They are available since January 1987 and are updated on a monthly basis. Because of the more limited nature of IBES, we are left with 42 firms. Over our sample, 7 firms were not referenced on the tape at the time of listing but began to be followed by analysts the month after listing. The forecasting horizon is held constant for each firm. The null hypothesis that the earnings forecast revisions are insignificant around the listing on the $R M$ market is tested in the following way:

( $H_{0}: \frac{\Delta E P S}{E P S}=0$ vs $H_{1}: \frac{\Delta E P S}{E P S} \neq 0$ where $\frac{\Delta E P S}{E P S}=\frac{1}{n} \sum_{i} \frac{E P S_{B+t, i}-E P S_{B, i}}{E P S_{B, i}}$

$2 H_{0}: \operatorname{Ln}(E P S)=0$ vs $H_{1}: \operatorname{Ln}(E P S) \neq 0 \quad$ where $\operatorname{Ln}(E P S)=\frac{1}{n} \sum_{i} \operatorname{Ln}\left(E P S_{B+t, i} / E P S_{B, i}\right)$

3 $H_{0}: p_{R}=0.5$ vs $H_{1} p_{R}>0.5:$ where $p_{R}=\frac{1}{n} \sum_{i} I_{j}$ and $I_{j}=\left\{\begin{array}{l}1 \text { if } E P S_{A, j}>E P S_{B, j} \\ 0 \text { if } E P S_{A, j}<E P S_{B, j}\end{array}\right.$

$E P S_{B, i}$ is the mean of the earnings forecast for firm $i$ the month before the announcement of listing on the $R M$ market, $t$ is the number of months after $B$ (the month before listing) and $n$, the numbers of observations. To allow for a slow reaction of analysts, two horizons are considered: one month and three months. Most of the time, we are not able to disentangle the last earnings forecast before the announcement and the listing because these dates are too close. Table 4 below shows that the revision of earnings forecasts is not significant at the usual level whatever the statistic test is.

Table 4: Revision in earning forecasts around listing announcement

\begin{tabular}{lccccccc}
\hline $\begin{array}{c}\text { Sample: } \\
\text { 42 obs. }\end{array}$ & Mean & 1 & $t$-stat & Mean & t-stat & Negative (\%) & $z$-stat \\
\hline 1 Month & 0.05 & 1.51 & 0.03 & 1.55 & 31 & 0.91 & 0.31 \\
3 Months & 0.03 & 0.84 & 0.01 & 0.60 & 48 & 0.31 \\
\hline
\end{tabular}

However, we must show that abnormal returns are still present. In fact, we find a positive and significant reaction at both the announcement $(0.54$ with $t$-stat $=2.08)$ and listing $(0.62$ with $t$ - 
stat $=2.19$ ) for the restricted sample ${ }^{15}$. At the aggregate level, no significant information related to expected earnings is conveyed at the announcement and the link with abnormal returns is rejected.

\subsection{The revision of systematic risk}

Listing by itself may convey information related to the riskiness of future cash flows (i.e. after listing, future cash flows may be perceived as less risky). In this case a positive reaction may arise because the expected return is reduced. Recently, Denis and Kadlec [1994] have shown that systematic risk estimates are affected by corporate events such as equity offerings and share repurchase. Because listing on the $R M$ is likely to increase the trading activity, we suspect an increase in the systematic risk after the event as well. This is a possible source of spurious negative returns after the event. In order to test this hypothesis, first we examine the number of days with trades before and after listing. The median of the percentage of days with trades is 97.3 before listing and 99.60 after and the difference of medians is highly significant $(z$-stat $=6.46)$. Second, the OLS estimators are corrected by using the technique proposed by Scholes and Williams [1977] and extended by Cohen et al. [1983]. Market model parameters are estimated as follows:

$$
\hat{\lambda}_{j}^{n}=\bar{r}_{i}-\hat{\beta}_{j}^{n} \bar{r}_{m} \quad \hat{\beta}_{j}^{n}=\frac{\sum_{t=1}^{n} \hat{\beta}_{j, \text { OLS }}^{-t}+\hat{\beta}_{j, O L S}+\sum_{t=1}^{n} \hat{\beta}_{j, O L S}^{t}}{1+\sum_{t=1}^{n} \hat{\rho}_{m}^{-t}+\sum_{t=1}^{n} \hat{\rho}_{m}^{t}}
$$

where $\hat{\beta}_{j, O L S}^{-t}\left(\hat{\boldsymbol{\beta}}_{j, O L S}^{t}\right)$ is the OLS coefficient from regressing contemporaneous stocks returns on the market returns lagging (leading) by $t$ periods, and $\hat{\beta}_{j, O L S}$ is the OLS coefficient from regressing contemporaneous stocks returns on market returns, $\hat{\rho}_{m}^{-t}\left(\hat{\rho}_{m}^{t}\right)$ is the $t$ periods autocorrelation of the market returns from the first (last) $T-t$ and $T$ is the number of observations.

These parameters were also computed with the method described in Dimson [1979]. The results are nearly identical and are not presented here. In table 5a, we report the cross-sectional mean and median of the beta estimates. The changes in mean (median) are tested using a standard $t$-test ( $z$-test). The descriptive statistics are significant at the usual level with zero, one and two leads and lags but they are found to be insignificant with three, four and five leads and lags. Before listing, OLS beta estimates are surprisingly low but there is an upward revision and the sample mean is close to one when more lags are considered. As noticed by Cohen et al. (1986), the longer the price adjustment delay, the more the OLS beta tends toward zero. Our results are close to those obtained by Denis and Kadlec [1994, p. 1797] and Vijh [1994, p. 247] in another setting. These results do not preclude negative abnormal returns after listing when OLS estimates are used instead of Cohen et al. estimates.

\footnotetext{
${ }^{15}$ Bootstrap $t$-stat were computed because of the reduced sample size and found to be 2.04 and 1.98 respectively.
} 
Table 5a: Changes in systematic risk around listing

\begin{tabular}{lcccccccc}
\hline \multicolumn{1}{c}{$\begin{array}{c}\text { Estimated Betas } \\
\text { (60 obs.) }\end{array}$} & \multicolumn{2}{c}{ Before } & \multicolumn{3}{c}{ After } & \multicolumn{4}{c}{ Change } \\
in & Median & Mean & Median & in Mean & $t$-stat & in Median & $z$-stat \\
\hline OLS & 0.55 & 0.54 & 0.88 & 0.89 & 0.34 & 6.36 & 0.32 & 6.46 \\
I lead, 1 lag & 0.82 & 0.78 & 1.01 & 1.09 & 0.19 & 3.46 & 0.16 & 2.98 \\
2 lead, 2lags & 0.94 & 0.86 & 1.04 & 1.11 & 0.11 & 1.84 & 0.18 & 1.65 \\
3 lead, 3 lags & 0.98 & 0.88 & 1.05 & 1.11 & 0.07 & 1.16 & 0.17 & 1.12 \\
4 lead, 4 lags & 0.93 & 0.90 & 0.99 & 0.81 & 0.05 & 0.81 & 0.10 & 1.90 \\
5 leads, 5 lags & 0.95 & 0.90 & 0.99 & 0.97 & 0.04 & 0.57 & 0.04 & 0.71 \\
\hline
\end{tabular}

Values in bold italics (bold) are significant at $1 \%(5 \%)$ level.

To get an insight on the robustness of the results previously found (see Table 3), abnormal and cumulated returns were computed with Cohen et al. estimates with one and five lead-lags. In order to test the null hypothesis of no abnormal returns, the series of abnormal returns were bootstrapped with 250 replications. Along this procedure, abnormal returns are assumed to be independently distributed. This assumption is reasonable because listings are not clustered in time. The bootstrap $t$-stat is computed as described in Efron and Tibshirani [1993, p. 226]. Abnormal returns are equal to 0.80 with 1 lead-lag (bootstrap $t$-stat $=3.32$ ) and 0.94 with 5 leads-lags (bootstrap $t$-stat $=4.09)$ at the announcement date and 1.11 (bootstrap $t$-stat $=2.87$ ) with 1 lead-lag and 1.12 (bootstrap $t$-stat $=3.10$ ) with 5 leads-lags at the time of listing. These figures are nearly identical to those obtained previously. Over a short period of time, abnormal returns are not affected by the way the parameters of the market model are computed.

Table 5b: Changes in alphas around listing

\begin{tabular}{lcccccccc}
\hline $\begin{array}{l}\text { Estimated Alphas } \\
\text { (60 obs.) }\end{array}$ & \multicolumn{2}{c}{ Before } & \multicolumn{2}{c}{ After } & \multicolumn{4}{c}{ Change } \\
\hline OLS & 0.14 & 0.15 & -0.06 & -0.02 & -0.20 & -8.18 & -0.17 & -9.68 \\
1 lead, 1 lag & 0.12 & 0.13 & -0.05 & -0.02 & -0.17 & -7.69 & -0.14 & -10.61 \\
2 lead, 2lags & 0.11 & 0.12 & -0.06 & -0.02 & -0.16 & -7.32 & -0.12 & -10.49 \\
5 leads, 5 lags & 0.10 & 0.11 & -0.05 & -0.03 & -0.16 & -6.28 & -0.12 & -7.17 \\
\hline
\end{tabular}

These number are rounded values: this is why Column Before less Column After is not always equal to Column Change. Values in bold italics are significant at $1 \%$.

Until now, we have shown that changes in the estimated coefficients produce insignificant average differences. In table $5 \mathrm{~b}$, we exhibit the average values of the alpha coefficient estimated with different leads and lags. In fact, the changes in alpha before and after listing are reduced when we use the Cohen et al. estimators. However, the average of the changes remains highly significant with 5 leads-lags and it is negative. These results show that the 
alphas are decreasing (in average) while betas are roughly constant, confirming our conjecture that expected returns are lower after listing than before.

\section{The price of liquidity and institutional setting}

Until 1989, an investor initiating a trade had to pay fixed commissions to the Société de Bourse. These commissions were related to the order size but not to the market where the firm was listed. The elimination of fixed commissions has had a mixed effect. Small orders are more expensive now but the decrease in transaction costs for large orders possibly offsets this effect at the aggregate level of the firm.

An important component of the trading costs is the cost of immediacy. Amihud and Mendelson [1986, p. 246] proposed a model in which the expected return for a security is an increasing function of the spread. Other things being equal, the difference in liquidity can induce price variations above $25 \%$. These results were empirically validated (see Amihud and Mendelson [1989, p. 484]). In our case, an improvement in liquidity should result in a fall of the expected return, which in turn implies an increase in the present price. However, Dubofsky and Groth [1984] proved that the liquidity of OTC securities decreases after listing on the AMEX or the NYSE. Conflicting results were obtained by Klemkosky and Conroy [1985]. Using transactions data, Christie and Huang [1994] established that trading costs are directly related to the spread and inversely related to the trade size.

Listing location may serve as proxy for liquidity. Mac Connell and Sanger [1987] have shown that the abnormal returns remain both with the AMEX or the NYSE as final market. The market by itself is not sufficient to explain the abnormal returns and this is why market microstructure has to be explored.

\subsection{The introduction of the CAC. System}

As we have seen before, the market microstructure of the French market has changed frequently over the period of this study. From 1985 to 1986, the Official list was a call market and the spread was not observable. At the beginning of 1986, the CAC system (continuous computerised trading) was implemented but, to our knowledge, no trade by trade data base is available for the period under study. We re-examine the reactions of the market depending on whether or not the firm was traded previously in continuous time with the CAC System. The main reason for considering the new trading system as an explanatory variable is that it may 
Table 6: Abnormal return before and after the introduction of continuous trading

\begin{tabular}{|c|c|c|c|c|c|c|c|c|c|c|c|c|c|c|c|c|}
\hline \multicolumn{9}{|c|}{ Announcement } & \multicolumn{7}{|c|}{ Listing } & \\
\hline & \multicolumn{4}{|c|}{ Before CAC } & \multicolumn{4}{|c|}{ After CAC } & \multicolumn{5}{|c|}{ Before CAC } & \multicolumn{3}{|c|}{ After CAC } \\
\hline & $\mathrm{AR}$ & CAR & $\mathrm{KS}$ & BMP & $\mathrm{AR}$ & CAR & $\mathrm{KS}$ & BMP & $\mathrm{AR}$ & CAR & $\mathrm{KS}$ & BMP & $\mathrm{AR}$ & CAR & $\mathrm{KS}$ & BMP \\
\hline-5 & 0.04 & 0.04 & 0.09 & 0.07 & -0.33 & -0.33 & -1.02 & -0.98 & 0.52 & 0.52 & 1.51 & 1.25 & -0.22 & -0.22 & -0.65 & -0.72 \\
\hline-4 & 0.13 & 0.17 & 0.37 & 0.33 & 0.28 & -0.06 & 0.97 & 1.44 & -0.44 & 0.08 & -0.81 & -0.82 & 0.00 & -0.22 & 0.20 & 0.23 \\
\hline-3 & 0.37 & 0.54 & 0.82 & 0.90 & -0.23 & -0.28 & -0.73 & -0.88 & 0.80 & 0.88 & 1.85 & 2.01 & 0.04 & -0.18 & 0.42 & 0.42 \\
\hline-2 & 0.20 & 0.74 & 0.22 & 0.19 & -0.36 & -0.64 & -1.25 & -1.58 & 0.96 & 1.83 & 1.99 & 1.62 & 0.43 & 0.26 & 1.33 & 1.25 \\
\hline-1 & 0.89 & 1.63 & 2.00 & 1.83 & -0.46 & -1.10 & -1.13 & -1.22 & -0.09 & 1.74 & -0.42 & -0.40 & 0.02 & 0.28 & 0.41 & 0.49 \\
\hline 0 & 0.49 & 2.12 & 1.12 & 2.07 & 0.08 & -1.02 & 0.18 & 0.24 & 2.03 & 3.77 & 3.80 & 2.94 & 0.66 & 0.94 & 1.64 & 1.39 \\
\hline 1 & 0.91 & 3.03 & 1.64 & 2.66 & 0.72 & -0.30 & 1.96 & 2.48 & 0.60 & 4.38 & 1.30 & 1.18 & -0.45 & 0.48 & -1.51 & -1.31 \\
\hline 2 & -0.10 & 2.93 & -0.38 & -0.39 & 0.38 & 0.07 & 1.28 & 1.20 & -1.23 & 3.15 & -2.40 & -2.09 & -0.13 & 0.35 & -0.28 & -0.37 \\
\hline 3 & 0.26 & 3.20 & 0.68 & 0.66 & -0.13 & -0.05 & -0.21 & -0.19 & -0.19 & 2.96 & -0.27 & -0.28 & 0.18 & 0.53 & 0.56 & 0.65 \\
\hline 4 & 0.12 & 3.31 & 0.15 & 0.16 & 0.22 & 0.17 & 0.73 & 0.71 & -0.86 & 2.10 & -1.31 & -1.13 & 0.44 & 0.97 & 1.26 & 1.53 \\
\hline 5 & -0.21 & 3.11 & -0.19 & -0.27 & 0.36 & 0.53 & 1.65 & 1.85 & -1.00 & 1.11 & -1.91 & -1.90 & -0.38 & 0.59 & -0.96 & -1.15 \\
\hline
\end{tabular}

Values in bold italics (bold) are significant at $1 \%(5 \%)$ level.

The number of firms listed before the introduction of the CAC system is 22 and the number of firms listed after is 38

The KS statistics is distributed as a standard normal under the null and the critical values are 2.56 (at $1 \%$ ) and 1.96 (at $5 \%$ ).

The BMD is statistics is as a student $t_{N-1}$ where $N$ is the number of firms. With $N=22$ the critical values at $1 \%$ is 2.83 and 2.08 at $5 \%$. With $\mathrm{N}=38$ these values are respectively 2.72 and 2.03 . 
contribute to increase the marketability of the shares. As it was shown by Longstaff (1995), the expected costs of nonmarketability can be large even when the illiquidity period is short $^{16}$. By reducing these costs, the CAC System may induce the increase in stock price after listing. The introduction of the NASDAQ system, for example, diminished significantly the positive effect of listing on the NYSE. For the Tel Aviv Stock Exchange, Amihud, Mendelson and Lauterbach $^{17}$ (1996) have found that an improvement in the trading system contributes to a permanent increase of 5.5 percent in stock prices. The importance of being listed on the $R M$ seems to be directly and strongly related to the change in trading system. Table 6 summarises the differences between the pre-CAC period and the post-CAC period. For the pre-CAC period, the gain over the two weeks surrounding the event $(\operatorname{CAR}[-5 ;+5])$ is 3.11 at the announcement of listing and 1.11 at the time of listing on the $R M$. When a more efficient trading system before and after listing is used (i.e. the post-CAC period), the cumulated abnormal returns are reduced to 0.53 and 0.59 and are not significant at the $5 \%$ level. At the listing date, abnormal returns is 2.03 for the pre-CAC and 0.66 for the post-CAC. However, these results are not a direct proof of the link between abnormal returns and the trading system. More specifically, we tested that average abnormal returns of firms listed during the pre-CAC and the post-CAC periods are equal. The results are presented in table 7.

Table 7: Abnormal returns before and after the introduction of continuous trading

\begin{tabular}{lccc}
\hline & pre-CAC period (22 obs.) & CAC period (38 obs.) & $t$-test \\
\hline Announcement & 0.91 & 0.72 & 0.11 \\
Listing & 2.03 & 0.66 & 0.49 \\
\hline
\end{tabular}

The z-test is computed as follows: $t=\frac{A R_{B}-A R_{A}}{\sqrt{\frac{n_{B} s_{B}^{2}+n_{A} s_{A}^{2}}{n_{B}+n_{A}-2}}}$ where $A R_{B}, s_{B}^{2}$ and $n_{B}\left(A R_{A}, s_{A}^{2}\right.$ and $\left.n_{A 1}\right)$ are the average abnormal returns, the variance of abnormal returns and the number of observations before (after) the introduction of the CAC.

The null hypothesis (the equality of average abnormal returns) is not rejected at the usual level of $5 \%$ and the positive impact of the new trading system is not established in an univariate frame.

\footnotetext{
${ }^{16}$ The discount is around $1.27 \%$ when the restriction is one day and the standard deviation of the stock is 0.30 per year (see Longstaff [1995, p. 1772, Table II]).

${ }^{17}$ Before the transfer, stocks are traded once a day a with call auction. After transfer, the trading mechanism enabled repeated continuous auctions.
} 


\subsection{Trading activity}

As it was underlined by Amihud and Mendelson [1988, p.13]: "The liquidity-increasing motive may explain the desire of many firms to list on the large and organised securities exchanges $॥$. The reduction of the cost of immediacy has an appealing feature because, as we have shown in section 3.2, there is a significant increase in the number of days with trades. Our hypothesis is that the trading volume increases after listing on the $R M$. In order to compare stocks whose prices are between FFR 100 and FFR 3000, daily transactions are normalised by using the following ratio:

$$
\operatorname{Rot}_{i, t}=\frac{\operatorname{Ln}\left[1+V o l_{i, t}\right]}{\operatorname{Ln}\left[1+N b t_{i, t}\right]}
$$

$\mathrm{Vol}_{i, t}$ is the number of shares traded per day and $\mathrm{Nbt}_{i, t}$, the number of shares listed.

This ratio measures share turnover and it was found to be normally distributed by Ajinkya et Pain [1989]. The null hypothesis of an increase in the share turnover is tested as follows:

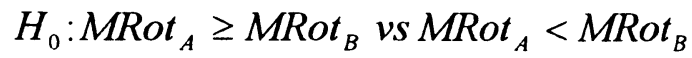

where $\operatorname{MRot}_{B}=\frac{1}{n} \sum_{i=1}^{n} \sum_{t=-T}^{-6+A} \operatorname{Rot}_{i, t}$ and $\operatorname{MRot}_{A}=\frac{1}{n} \sum_{i=1}^{n} \sum_{t=L+6}^{T} \operatorname{Rot}_{i, t}$

$A$ is the announcement date and $L$ the listing date. The eleven days of the window are eliminated and two periods are used to estimate the means: one hundred days and one year. Similar tests were conducted with trading volume instead of share turnover:

$$
\text { Lnvolffi, }=\operatorname{Ln}\left(\text { Volffr }_{i, t}\right)
$$

where olffr $r_{i, t}$ is the trading volume (expressed in FFR) of firm $i$ for day $t$.

Table 8: Share turnover and trading volume increase after listing

\begin{tabular}{lccccc}
\hline & \multicolumn{5}{c}{ Full sample (60 obs.) } \\
& Mean before & Mean after & Difference & $t$-stat & $z$-test \\
\hline Share turnover & & & & & \\
Change 100 days & 0.49 & 0.51 & 0.03 & 3.85 & 2.74 \\
Change 1 year & 0.49 & 0.51 & 0.04 & 5.74 & 4.47 \\
& & & & & \\
Trading volume & & 8.06 & 0.23 & 1.88 & 0.78 \\
Change 100 days & 7.83 & 8.17 & 0.54 & 4.50 & 4.88 \\
Change 1 year & 7.63 & & & & \\
\hline
\end{tabular}

Values in bold italics (bold) are significant at $1 \%(5 \%)$ level and the critical values for this one-sided test are 2.39 (1.67).

As expected, Table 8 shows a highly significant increase in share turnover and trading volume after listing on the $R M$. However, the change in trading volume is more important when computing the average daily trading volume over one year: one possible reason is that trading volumes are increasing continuously over the period ${ }^{18}$. Another explanation is that this series is positively skewed which in turn biased the $t$-stat. As expected, after accounting for skewness,

\footnotetext{
${ }^{18}$ The equality of daily share turnover during the periods $[-250 ;-101]$ and $[-100 ;-6]$ was strongly rejected.
} 
the $t$-stat becomes larger $(t$-stat $=2.19)$. All the above findings are not surprising because trading volume is used by the Société des Bourses Française to decide which firms are willing to switch on the $R M$.

\section{The access to information}

\subsection{Heterogeneous expectations and short selling}

Within the framework of the standard hypotheses of the Capital Asset Pricing Model, the homogenous expectations, free borrowing and lending at the risk free rate guarantee the existence of the market equilibrium which is not affected by the constraints on short sales. When the first hypothesis is removed, the shareholders and the other investors do not have a symmetric role any longer. The unfavourable expectations of the latter cannot be taken into account in the price formation process and, according to Mayshar [1983], this should result in an overvaluation of the assets for which short sales are forbidden or restricted. However, according to Jarrow [1980], the substitution effects combined with the restrictions on short sales influence the prices positively or negatively. The sign depends on the individual expectations of the variance-covariance matrix of the asset prices. As L'Her and Suret [1991, p. 139] pointed out in their survey, it is unlikely that such bias persists on the market as far as the hypothesis of rational expectations is accepted. However, Merton [1987, p. 505] prove that short sales constraints (or forbidding short sales) have a dissuasive effect upon the expensive information collection because investors cannot benefit from unfavourable information.

We examined the dispersion among the most optimistic and the most pessimistic forecasts around the listing (the months before and after listing) in order to test an increase in the heterogeneity of believes between investors. The following hypothesis was tested:

$H_{0}: R G\left(E P S_{A}\right)-R G\left(E P S_{B}\right)=0$ vs $H_{1}: R G\left(E P S_{A}\right)-R G\left(E P S_{B}\right) \neq 0$

where $R G\left(E P S_{A}\right)=\frac{\operatorname{Max}\left(E P S_{B}\right)-\operatorname{Min}\left(E P S_{B}\right)}{\operatorname{Med}\left(E P S_{B}\right)}$,

$\operatorname{Max}\left(\operatorname{EPS}_{B}\right)\left(\operatorname{Min}\left(E P S_{B}\right)\right)$ is the most optimistic (pessimistic) forecast among the analysts.

As it was observed elsewhere by Brown et al. [1985], the proportion of revisions on two consecutive periods is low (around 10\%). The number of upward and downward revisions is of the same order of magnitude and even lower (5\%). Once again, we do not reject the null $(t$-stat $=-1.38$ and $z$-test $=-0.79$ the month after listing and $t$-stat $=0.81$ and $z$-test $=1.01$ three month after listing) that the revisions are insignificant at the usual level. On average, the dispersion of earnings among analysts if roughly constant. However, the conclusion is mitigated because the sample size is reduced dramatically. For those firms for which we have 
information, abnormal returns are not significant at both the announcement or listing at the $5 \%$ level $(A R=0.34, t \text {-stat }=1.30)^{19}$.

\subsection{Listing on the RM and the giraffes ${ }^{20}$}

The quantity and the quality of the information available for each security are not homogenous among stocks. Firms listed on a more active market are more carefully followed by the analysts. By consulting the December 1994 forecasts on the IBES tape, we have observed that few securities of the $S M$ or of the $M C$ are referenced while the converse is true for all the securities listed on the $R M$. These firms are mostly followed by more than ten analysts. We are interested in determining if stocks listed on the $R M$ are more heavily followed by analysts than stocks listed on the $M C$ or the $S M$ market. Because Brennan et al. (1993) have shown that size is an important determinant of the number of analysts following a stock, firms are divided into quintile according to the market value. Each quintile is then divided by market segment.

Table 9: Analysts' following and market segment

\begin{tabular}{|c|c|c|c|c|c|}
\hline \multirow{2}{*}{$\begin{array}{l}\text { Mkt value in } \\
\text { million FFR }\end{array}$} & \multicolumn{5}{|c|}{ Full sample (349 firms) } \\
\hline & $300<$ & $300-1000$ & $1000-2700$ & $2700-7200$ & $>7200$ \\
\hline Percent. of $\mathrm{RM}^{\mathrm{a}}$ & 1 & 7 & 22 & 32 & 38 \\
\hline $\mathrm{N}$ analysts ${ }^{\mathrm{b}}$ & 3 & 8 & 11 & 18 & 29 \\
\hline Percent. of $\mathrm{MC}^{\mathrm{a}}$ & 21 & 25 & 33 & 19 & 2 \\
\hline $\mathrm{N}$ analysts ${ }^{\mathrm{b}}$ & 2 & 3 & 2 & 4 & 8 \\
\hline Percent. of $\mathrm{SM}^{\mathrm{a}}$ & 46 & 36 & 12 & 5 & 1 \\
\hline $\mathrm{N}$ analysts ${ }^{b}$ & 1 & 3 & 8 & 10 & 22 \\
\hline
\end{tabular}

${ }^{a}$ Percentage of firms in the quintile.

${ }^{b}$ Median of the number of analysts following the stocks in each quintile.

Table 9 clearly shows that the number of analysts increases with market value but, for each quintile, more analysts are following stocks listed on the $R M$. Large $M C$ and to a less extent $S M$ firms, are neglected by financial analysts. We are entitled to expect an increase in the number of analysts after listing on the $R M$. Hereafter, we study the consequences of these changes on the price of the securities.

Following Levy [1978], Merton [1987] noticed that investors do not hold diversified portfolios. Because information is costly, it may not be optimal for an investor to fully diversify his holdings. When each investor follows a limited number of securities, the market equilibrium is different from the one on a perfect market. The incomplete information schedule induces a

\footnotetext{
${ }^{19}$ Bootstrapped values are $A R=0.34$ and $t$-stat $=1.44$.

${ }^{20}$ This expression was used by Arbel et al. [1983, p. 57] because : « Institutions, mutual funds banks and money managers $[. .$.$] concentrate on the tall trees in the investment forest, ignoring the underbrush ».$
} 
market segmentation. The difference of expected return between segmentation $v s$ perfect market is described by the following relation:

$\bar{R}_{k}-R=\beta_{k}\left(\bar{R}_{M}-R\right)+\gamma_{k}$
where $\gamma_{k}=\lambda_{k}-\beta_{k} \lambda_{M} ; \quad \beta_{k}=\frac{b_{k} b+x_{k} \sigma_{k}^{2}}{\sigma_{M}^{2}}$ and $\lambda_{k}=\delta \frac{x_{k}}{q_{k}} \sigma_{k}^{2}\left(1-q_{k}\right)$ $\bar{R}_{k}$ is the expected return of one FFR invested in firm $k$ in the incomplete information case, $\bar{R}_{M}$ the return of the market portfolio and $R$ the return of the risk free rate,

$\lambda_{k}$ the parameter measuring the additional expected return (shadow cost),

${ }_{k}^{2}$ the specific variance of security $k, x_{k}$ is the relative weight of the firm in the market, $\delta$ the coefficient of risk aversion, $q_{k}$ the proportion of investors who know about security $k$, $\beta_{k}$ the systematic risk, $b$ the common factor exposure and $b_{k}$ the factor exposure of firm $k$.

Listing on a market followed more carefully by analysts, the Financial Press and in general by all the investors results, implies a reduction of $\lambda_{k}$. Indeed, other things being equal, a greater dispersion of the ownership resulting in an easier access to information reduces both $\lambda_{k}$ and the expected return. The adjustment results in a rise of the present price and may explain why the positive abnormal returns are observed at the announcement and the listing.

In Kadlec and Mc Connell [1994] study, abnormal returns are assumed to be linearly related to changes in $\lambda_{k}$ which are originated by an increase in the number of investors who know about the stock. They used the number of registered shareholders to proxy $q_{k}$. This proxy may be severely biased as underlined by Merton [1987, p. 498]. The reason is that a fraction of the shares are held by financial institutions. In this case, the number of individual stockholders underestimates the total number of investors who know about the stock.

In order to avoid this bias, we suggest to use the number of analysts following a stock as a proxy of the number of investors who know about it. Abnormal returns can even be progressive as the firm is followed by more and more analysts and the number of analysts which are going to follow the stock is not fully anticipated. We analyse the number of analysts following a stock around the switch on the $R M$ market. Using the same sample as in 2.2 , the null hypothesis of an increase in the number of analysts after listing is tested as follows:

$H_{0}: p^{+}=p^{-}$vs $H_{1}: p^{+}>p^{-}$

where $p^{+}=\frac{1}{n} \sum_{i} \varphi_{i}^{+}$and $p^{-}=\frac{1}{n} \sum_{i} \varphi_{i}^{-}$with $\varphi_{i}^{+}=\left\{\begin{array}{l}1 \text { if } N A_{A, i}>N A_{B, i} \\ 0 \text { otherwise }\end{array}\right.$ and $\varphi_{i}^{+}=\left\{\begin{array}{l}1 \text { if } N A_{A, i}<N A_{B, i} \\ 0 \text { otherwise }\end{array}\right.$ $n=$ Number of cases where $N A_{A, i} \neq N A_{B, i}$

$N A_{B, i}$ is the number of analysts following firm $i$ the month prior to listing and $N A_{A, i}$ this number the month after (or three months after). The null hypothesis of the number of analysts being constant before and after listing is not rejected $(z$-test $=1.33)$ one month after the listing; however the number of analysts increases when a three months horizon is considered ( $z$ - 
test $=6.67$ ). Stocks are more carefully followed by analysts when listed on the $R M$ but the abnormal returns for the stocks who experienced an increase (or a decrease) in the number of analysts is insignificant at the anouncement date $(A R=0.34, t$-stat $=1.30)$ and at the listing date $(A R=0.36, t$-stat $=0.90)$. Because the sample size is reduced dramatically ( 29 firms have a non constant number of analysts 3 months after listing), the bootstrap technique is used with 250 replications $(A R=0.35, t$-stat $=1.44$ at the announcement date and $A R=0.36, t$-stat $=$ 0.91 at the listing date). Nevertheless our results do not reject the null hypothesis. The main reason for this puzzling result seems to be that the increase in the number of analysts is too slight and too low in order to imply a significant market reaction: the median is equal to 2 (mean $=1.6$ ). Moreover, the number of analysts referenced in the IBES Europe History Tape may be a bad proxy because of the error in variable problem. During the period under study the data base was too new in order to avoid seasonality and growth effects.

\section{Abnormal return and changes in the parameters of the market model}

\subsection{The relation between abnormal returns and the changes in $\alpha$ and $\beta$}

Let us assume first that the investment horizon for all investors is $T$, and the compounded expected rate of return is $r$. The present value ${ }_{0}$ of the firm is:

$$
{ }_{0}=e^{-r T} E\left(\widetilde{V}_{T}\right)
$$

Let us assume now that the market model holds so $E(r)=\alpha+\beta E\left(r_{m}\right)$

If there is a shock in the expected rate of return caused by a shift in the parameters of the market model, we have:

$\frac{d V_{0}}{V_{0}}=-t d E(r)=-t\left[d \alpha+E\left(r_{m}\right) d \beta\right]$

and after taking finite differences:

$$
A R=\frac{\Delta V_{0}}{V_{0}}=-t\left[\Delta \alpha+E\left(r_{m}\right) \Delta \beta\right]
$$

Cross sectional variations in abnormal returns are examined by estimating the parameters of the following regression:

$$
A R_{k}=a_{0}+a_{1} \Delta \alpha_{k}+a_{2} \Delta \beta_{k}+u_{k}
$$

where $A R_{k}$ are the abnormal returns at the time of announcement and listing and $u_{k}$ is an error term.

From equation (1), the coefficients $a_{1}$ and $a_{2}$ are negative and $a_{0}$ is nil. In table 10 we report the results with both the announcement and the listing abnormal returns as dependent variables. When abnormal returns are measured at the date of listing, the regression is highly significant, the independent variables have the expected sign and the intercept is not different from zero. The explanatory power of the model increases when $\alpha$ and $\beta$ 's are estimated with the Cohen et al. method. Nevertheless, the model has no explanatory power at all when we use the abnormal 
returns estimated at the announcement date as dependent variable. These confounding results are confirmed when using different estimates of abnormal returns (i.e. those computed with the $\alpha$ and $\beta$ 's with one and five leads-lags).

Table 10: Abnormal returns at the announcement and listing dates and

\begin{tabular}{|c|c|c|c|c|c|c|}
\hline & \multicolumn{3}{|c|}{ Announcement } & \multicolumn{3}{|c|}{ Listing } \\
\hline & Intercept & $\Delta \alpha$ & $\Delta \beta$ & Intercept & $\Delta \alpha$ & $\Delta \beta$ \\
\hline OLS & $\begin{array}{l}0.42 \\
(1.22) \\
R^{2}=0.035\end{array}$ & $\begin{array}{l}-0.83 \\
(-0.72)\end{array}$ & $\begin{array}{l}0.58 \\
(1.05) \\
p-v a l=0.36\end{array}$ & $\begin{array}{l}-0.31 \\
(-0.64) \\
R^{2}=0.302\end{array}$ & $\begin{array}{l}\mathbf{- 8 . 1 1} \\
\mathbf{( - 4 . 9 5 )} \\
R^{2} \text { adj }=0.27\end{array}$ & $\begin{array}{l}-0.54 \\
(-0.69) \\
p-v a l=0.00\end{array}$ \\
\hline 5 leads, 5 lags & $\begin{array}{l}0.71 \\
(2.15) \\
R^{2}=0.034\end{array}$ & $\begin{array}{l}-1.15 \\
(-0.87)\end{array}$ & $\begin{array}{l}0.50 \\
(1.07) \\
p-v a l=0.37\end{array}$ & $\begin{array}{l}-0.09 \\
(-0.23) \\
R^{2}=0.312\end{array}$ & $\begin{array}{l}-7.70 \\
(-4.54) \\
R^{2} \text { adj. }=0.28\end{array}$ & $\begin{array}{l}-1.54 \\
(-2.55) \\
p-v a l=0.00\end{array}$ \\
\hline
\end{tabular}

$t$-stat are in parenthesis. Values in bold italics (bold) are significant at $1 \%(5 \%)$ level.

$\mathrm{AR}$ and the independent variables are computed with the standard market model and with the market model using $\alpha$ and $\beta$ with 5 leads-lags.

However, as noticed by Merton [1987, p. 500-501]: « Nevertheless, if the form of the prior public release of the information did not capture widespread attention among investors who do not follow the stock and if the new form does, the firm's investor base will increase and the stock price rise » and help to explain why abnormal returns at the listing are correctly described by the model. In fact, this is precisely what we observed: the Financial Press reports the listings on the RM the day it occurs (or sometimes the day before) but not around the official announcement date.

\subsection{Checking the robustness of the model}

Changes in the parameters of the market model after listing provide a good explanation of abnormal returns at the time of listing. Liquidity was found to be insignificantly related to abnormal returns (see section 4). However, those relations were examined in an univariate setting which may lead to spurious results. In order to check the robustness of the results, we re-examine the model by adding successively the trading system, turnover, trading volume and the net position at the end of the first settlement period as independent variable. To be more precise, the following model is tested:

$$
A R_{k}=a_{0}+a_{1} \Delta \alpha_{k}+a_{2} \Delta \beta_{k}+a_{3} X_{k}+u_{k}
$$

with $X_{k}$ being one of the above mentioned variables. In Table 11, the results are summarised. None of these variables is significant at $5 \%$ level except the net position (Npos). The increase in trading volume is significant at the margin but most of the explanatory power seems to be 
due to the high correlation of this variable with Npos. When both variables are used jointly, trading volume is no longer significant (the results are not reported here).

Table 11: Abnormal returns at listing, liquidity and net position

\begin{tabular}{|c|c|c|c|c|}
\hline \multirow{3}{*}{$\frac{\text { Equation }}{\text { Intercept }}$} & 1 & 2 & 3 & 4 \\
\hline & 0.59 & -0.11 & -0.46 & -0.26 \\
\hline & $(0.91)$ & $(-0.21)$ & $(-1.02)$ & $(-0.66)$ \\
\hline \multirow[t]{2}{*}{$\Delta \alpha$} & -7.17 & -7.71 & -8.00 & -5.36 \\
\hline & $(-4.16)$ & $(-4.43)$ & $(-4.82)$ & $(-3.15)$ \\
\hline \multirow[t]{2}{*}{$\Delta \beta$} & -1.61 & -1.54 & -1.62 & -1.49 \\
\hline & $(-2.68)$ & $(-2.50)$ & $(-2.75)$ & $(-2.68)$ \\
\hline$D C A C$ & $\begin{array}{l}-0.93 \\
(-1.39)\end{array}$ & & & \\
\hline$\Delta R o t$ & & $\begin{array}{c}0.24 \\
(0.04)\end{array}$ & & \\
\hline$\Delta$ Lnvolffr & & & $\begin{array}{c}0.49 \\
(\mathbf{1 . 9 8})\end{array}$ & \\
\hline Npos & & & & $\begin{array}{c}0.22 \\
(3.42)\end{array}$ \\
\hline$R^{2}$ & 0.34 & 0.31 & 0.36 & 0.43 \\
\hline$R^{2}$ adj & 0.30 & 0.28 & 0.32 & 0.40 \\
\hline
\end{tabular}

$t$-stat are in parenthesis and the corresponding values in bold italics (bold) are significant at $1 \%(5 \%)$.

Abnormal returns at the time of listing are computed with the Cohen et al. estimator with five leads and lags. $D C A C$ is dummy variable equal to 1 when the firm was listed on the CAC System before and after listing on the $R M . \Delta R o t$ is a measure of the mean daily turnover (as defined previously in section 4) over the year after listing less the mean daily turnover over the year before listing. $\Delta$ Lnvolffr is calculated by replacing the turnover by the FFR share trading volume. Npos is the net position (long position less short position) at the end of the first settlement period after listing.

Now, what is new is that Npos is highly significant. The other variables in the model remain significant and negative as we found previously. The possibility to use leverage is anticipated by market participants in the sense that the market reacts one month before the net position is known by market participants. The market reaction is likely to be the expected value of the new investors attracted by the firm. It is interesting to note that the net position is almost always positive ( 46 firms over 60 ) or nul ( 9 firms over 60 ).

\section{Conclusion}

The aim of this paper was to study the market reaction when stocks are listed on the $R M$ market. As elsewhere, an abnormal price increase is observed in France at both the announcement and the listing date. We listed and tested the financial causes which can explain this positive reaction: the informational content of the operation, the decrease in the systematic risk, the increase in trading activity and the changes that the French Market experienced during 
the period under study. The informational content hypothesis was rejected because the revision in earning forecasts around listing was found to be insignificant. The systematic risk was found to be constant on average after adjusting for nonsynchronous trading. The introduction of the CAC system reduced slightly (but not significantly) the benefits of listing and the trading volume increased significantly after listing.

We have shown how abnormal returns are related to the changes in the parameters of the market model. Our test consists in exploiting the linear relation between the abnormal returns and the increase in $\alpha$ and $\beta$ after listing on the $R M$. This relation was found to explain the abnormal returns at the listing quite well: the coefficients have the expected sign and the intercept in the regression model is not significant. This model was found to be robust to the addition of variables measuring liquidity (the increase in both turnover and trading volume, the new trading system and the marketability): these variables do not improve significantly the explanatory power of the model. Nevertheless, we cannot reject the hypothesis that liquidity plays a role at least because it has a strong impact on $\alpha$ and $\beta$. The possibility to take levered and short positions add power in explaining abnormal returns. A possible reason is that new shareholders are investing in the firm because they can benefit from both overpricing or underpricing whioch was not the case before listing on the $R M$. Nevertheless, the model does not explain the price behaviour at the announcement. This question is left for further research. 
Appendix

A.1: Market reactions around the listing on a major market

\begin{tabular}{|c|c|c|c|c|}
\hline \multirow[t]{2}{*}{ Study } & \multirow{2}{*}{$\begin{array}{l}\text { Sample } \\
\text { period, n obs., country }\end{array}$} & \multirow[t]{2}{*}{ Model } & \multicolumn{2}{|c|}{ Abnormal return } \\
\hline & & & before & after \\
\hline \multirow[t]{3}{*}{ Van Horne[1970] } & $60-67,140$, USA & SAR & & \\
\hline & bullish market & & $>0$ & 0 \\
\hline & bearish market & & 0 & 0 \\
\hline Ying et al. [1977] & $66-68,248$, USA & CAPMAR & $>0$ & $<0$ \\
\hline Fabozzi[1981] & $72-75,83$, USA & MMAR & $>0$ & $<0$ \\
\hline Sanger and Mc Connell [1986] & $66-77,319$, USA & MMAR & $>0$ & $<0$ \\
\hline Mc Connell and Sanger [1987] & $26-82,2482$, USA & MAR & n.s. & $<0$ \\
\hline \multirow[t]{3}{*}{ Grammatikos and Papaioannou [1986-a] } & $75-81,88$, USA & MMAR & & \\
\hline & liquid securities & & n.s. & $<0$ \\
\hline & not liquid securities & & n.s. & $<0$ \\
\hline \multirow[t]{3}{*}{ Grammatikos and Papaioannou [1986-b] } & 75-81, 88, USA & MMAR & & \\
\hline & outstanding & & 0 & 0 \\
\hline & not outstanding & & $>0$ & $<0$ \\
\hline \multirow[t]{2}{*}{ Dubois [1993] } & 77-89, 75, FR & MAR & $>0$ & $<0$ \\
\hline & & MMAR & $>0$ & $<0$ \\
\hline Hwang and Jayaraman [1993] & 75-89, 56, JAP & MAR & n.s. & $<0$ \\
\hline Kadlec and Mc Connell[1994] & $80-89,273$, USA & MMAR & $>0$ & $<0$ \\
\hline Dharan and Ikenberry [1994] & $62-90,2889$, USA & PAR & n.s. & $<0$ \\
\hline
\end{tabular}

n.s. not studied, SAR (sector adjusted return), MMAR (market model adjusted return), MAR (market adjusted return),

CAPMAR (CAPM adjusted return) and PAR (adjusted for book to market and size portfolio). 


\section{A.2 Correction of the market index for the cost of carry}

This correction is important especially since the event occurs on the day with the greatest saving of cost of carry which is computed using calendar days:

$P_{t, \tau_{t}}^{F}=P_{t}^{C}\left(1+\frac{r_{t} \times \tau_{t}}{360}\right)$ where:

$P_{t, \tau_{t}}^{F}=$ Price at time $t$ of a stock (or an index) settled at time $t+\tau_{t}$,

$P_{t}^{C}=$ Spot price at time $t$ considering an instantaneous cash settlement,

$r_{t}=$ Spot interest rate on day $t$ ending at $t+\tau_{t}$,

$\tau_{t}=$ Length of the interval of time between transaction and payment.

Daily returns computed over two settlement periods

$R_{t}^{F}=\operatorname{Ln} \frac{P_{t, \tau_{t}}^{F}}{P_{t-1, \tau_{t-1}}^{F}}=\operatorname{Ln} \frac{P_{t}^{C}}{P_{t-1}^{C}}+\operatorname{Ln} \frac{1+r_{t} \times \tau_{t} / 360}{1+r_{t-1} \times \tau_{t-1} / 360}$

$R_{t}^{F}=R_{t}^{C}+\operatorname{Ln} \frac{1+r_{t} \times \tau_{t} / 360}{1+r_{t-1} \times \tau_{t-1} / 360}$

Assuming $r_{t} \approx r_{t-1}=r$ for consecutive days

$R_{t}^{C}=R_{t}^{F}-\operatorname{Ln} \frac{1+r \times \tau_{t} / 360}{1+r \times \tau_{t-1} / 360} \cong R_{t}^{F}-\frac{r}{360}\left(\tau_{t}-\tau_{t-1}\right)$

The corresponding value of the market index is computed for each stock. The parameters of the market model are computed using the cash value (forward) of the index before (after) listing. Assuming a constant risk free rate during a given month and other things being equal, it can be easily shown that the parameters of the market model remain unchanged.

\section{Daily returns computed during a settlement period}

Assuming a constant spot rate $r$, we have the following relation:

$R_{t}^{F}=\operatorname{Ln} \frac{P_{t, \tau_{t}}^{F}}{P_{t-1, \tau_{t}}^{F}}=\operatorname{Ln} \frac{P_{t}^{C}}{P_{t-1}^{C}}+\operatorname{Ln} \frac{1+r \times \tau_{t} / 360}{1+r \times \tau_{t-1} / 360}$

$R_{t}^{C} \cong R_{t}^{F}-\frac{r}{360}\left(\tau_{t}-\tau_{t-1}\right)>R_{t}^{F}$ because $\tau_{t-1}>\tau_{t}$

The SBF 250 index is corrected using both formulas in order to obtain the cash values. 


\section{References}

Ajinkya B. and P. Pain, 1989, The Behavior of Daily Stock Market Trading Volume, Journal of Accounting and Economics, vol. 11, 331-359.

Amihud Y. and H. Mendelson, 1986, Asset Pricing and the Bid-Ask Spread, Journal of Financial Economics, vol. 17, 223-249.

Amihud Y. and H. Mendelson, 1988, Liquidity and Asset Pricing: Financial Management Implications, Financial Management, vol. 17, 5-15.

Amihud Y. and H. Mendelson, 1989, The Effect of Beta, Bid-Ask Spread, Residual Risk, and Size on Stock Returns, Journal of Finance, vol. 44, 479-486.

Amihud Y., H. Mendelson and B. Lauterbach, 1996, Market Microstructure and Securities Values: Evidence from the Tel Aviv Stock Exchange, Working Paper, New York University Stern School, 44 p.

Arbel A., S. Carvell and P. Strebel, 1983, Giraffes, Institutions and Neglected Firms, Financial Analyst Journal, May-June, 57-63.

Bancel F. and C. Vai, 1994, Impact sur les prix et les volumes des titres introduits ou sortants du panier de $l^{\prime}$ indice CAC40, Analyse Financière, $n^{\circ}$ 101, 78-90.

Baker H. and M. Johnson, 1990, A Survey of Management's View on Exchange Listing, Quarterly Journal of Business and Economics, vol. 29, 3-20.

Barone E., 1990, The Italian Stock Market Efficiency and Calendar Anomalies, Journal of Banking and Finance, vol. 14, 483-510.

Beneish M.D. and R.E. Whaley, 1996, An Anatomy of the 'S\&P Game': The Effects of Changing the Rules, Journal of Finance, vol. 51, 1909-1930.

Boehmer E., J. Musumeci and A. Poulsen, 1991, Event Study Methodology under Conditions of Event-Induced Variance, Journal of Financial Economics, vol. 30, 253-272.

Brennan M., N. Jegadeesh and B. Swaminathan, 1993, Investment Analysis and the Adjustment of Stock Prices to Common Information, Review of Financial Studies, vol. 6, 799-824.

Brown P., G. Foster and E. Noreen, 1985, Security Analyst Multi-year Earnings Forecasts and Capital Market, Studies in Accounting Research, vol. 21, American Accounting Association.

Brown S.J. and J.B. Warner, 1985, Using Daily Stock Returns - The Case of Event Studies, Journal of Financial Economics, vol. 14, 3-31.

Christie W. and R. Huang, 1994, Market Structures and Liquidity: A Transaction Data Study of Exchange Listings, Journal of Financial Intermediation, vol. 3, 300-326.

Cohen K., G. Hawawini, S. Maier, R. Schwartz and D. Whitcomb, 1983, Frictions in the Trading Process and the Estimation of the Systematic Risk, Journal of Financial Economics, vol. 12, 263-278.

Cohen K., S. Maier, R. Schwartz and D. Whitcomb, 1986, The Microstructure of Securities Markets, Prentice-Hall.

Cowan A. and A. Sergeant, 1996, Trading Frequency and Event Study Test Specification, Journal of Banking and Finance, vol. 20, 1731-1757.

Dharan B. G. and D. Ikenberry, 1995, The Long Run Negative Drift of Post-Listing Stock Returns, Journal of Finance, vol. 50, 1547-1574.

Denis D. and G. Kadlec, 1994, Corporate Events, Trading Activity, and the Estimation of Systematic Risk: Evidence From Equity Offerings and Share Repurchases, Journal of Finance, vol. 49, 1787-1811.

Dhillon U. and H. Johnson, 1991, Changes in the Standard and Poor's 500 List, Journal of Business, vol. 64, 75-85.

Dimson E., 1979, Risk Measurement when Shares are Subject to Infrequent Trading, Journal of Financial Economics, vol. 7,197-226.

Donders M. and T. Vorst, 1996, The Impact of Firm-Specific News on Implied Volatilities, Journal of Banking and Finance, vol. 7, 1447-1462.

Dubofsky D. and J. Groth, 1984, Exchange Listing and Stock Liquidity, Journal of Financial Research, vol. 7, 291-302.

Dubois M., 1993. Transferts sur le marché à règlement mensuel: les réactions du marché, Finance, vol. 14, $41-65$.

Efron B. and R. Tibshirani, 1993, An Introduction to the Bootstrap, Chapman and Hall.

Fabozzi F., 1981, Does Listing on the AMEX Increase the Value of Equity ? Financial Management, vol. 10, 43-50.

Fabozzi F. and R. Hershkoff, 1979, The Effect of the Decision to List on a Stock's Systematic Risk, Review of Business and Economic Research, vol. 14, 77-82.

Fowler D.J. and C.H. Rorke, 1983, Risk Measurement when Shares are Subject to Infrequent Trading: Comment. Journal of Financial Economics, vol. 12, 279-283.

Goulet W., 1974, Prices Changes, Managerial Actions and Insider Trading at the Time of Listing, Financial Management, vol. 3, 30-36. 
Grammatikos T. and G. Papaioannou, 1986, Market Reaction to NYSE Listings: Tests of the Marketability Gains Hypothesis, Journal of Financial Research, vol. 9, 215-227.

Grammatikos T. and G. Papaioannou, 1986, The Informational Value of Listing on the NYSE, Financial Review, vol. 21, 485-499.

Hamon J. and B. Jacquillat, 1992, Le marché français des actions: études empiriques 1977-1991, Presses Universitaires de France.

Harris, L.E. and E. Gurel, 1986, Price and Volume Effects Associated with Changes in the S\&P 500 List: New Evidence for the Existence of Price Pressures, Journal of Finance, vol. 41, 815-829.

Huang R. and H. Stoll, 1991, Major World Equity Markets Current Structure and Prospects for Change, Monograph Series in Finance and Economics, 1991-3 New York University, Salomon Brother Center.

Hwang C. and N. Jayaraman, 1993, The Post Listing Puzzle: Evidence from Tokyo Stock Exchange Listings, Pacific-Basin Finance Journal, vol. 1, 111-126.

Ikenberry D., J. Lakonishok and T. Vermaelen, 1995, The Long Run Negative Drift of Post-Listing Stock Returns, Journal of Financial Economics, vol. 39, 181-208.

Jain P.C., 1987, The Effect on Stock Price of Inclusion in or Exclusion from S\&P 500, Financial Analysts Journal, January-February, 58-65.

Jarrow R., 1980, Heterogeneous Expectations, Restrictions on Short Sales and Equilibrium Asset Prices, Journal of Finance, vol. 35, 1105-1114.

Kadlec G. B. and J. J. Mac Connell, 1994, The Effect of Market Segmentation and Illiquidity on Asset Prices: Evidence from Exchange Listings, Journal of Finance, vol. 49, 611-636.

Karafiath I. and D. Spencer, 1991, Statistical Inference in Multiperiod Event Studies, Review of Quantitative Finance and Accounting, vol. 1, 353-371.

Karoly G. A., 1996, What happens to Stocks that List Shares Abroad? A Survey of Evidence and its Managerial Implications, Working Paper $\mathbf{n}^{\circ}$ 96-27, Richard Ivey School of Business, University of Western Ontario.

Klemkosky R. and R. Conroy, 1985, Competition and the Cost of Liquidity to Investors, Journal of Economics and Business, vol. 37, 183-195.

Levy H., 1978, Equilibrium in an Imperfect Market: a Constraint on the Number of Securities in the Portfolio, American Economic Review, vol. 68, 643-658.

Longstaff F. A., 1995, How Much Can Marketability Affect Security Values?, Journal of Finance, vol. 50, 1767-1774.

Loughram T. and J.R. Ritter, 1995, The New Issues Puzzle, Journal of Finance, vol. 50, 23-51.

Lynch A.W. and R.R. Mendenhall, 1995, New Evidence on Stock Price Effects Asociated with Changes in the S\&P 500 Index, FEN, $46 \mathrm{p}$.

Mac Connell J. J. and G. C. Sanger, 1987, The Puzzle in Post-Listing Common Stock Returns, Journal of Finance, vol. 42, 119-140.

Merton R., 1987, A Simple Model of Capital Market Equilibrium with Incomplete Information, Journal of Finance, vol. 42, 483-510.

Patell J., 1976, Corporate Forecasts of Earnings per Share and Stock Price Behavior : Empirical Tests, Journal of Accounting Research, vol. 14, 246-276.

Prakash A. J., A.M. Parhizgari and G. Perritt, 1989, The Effect of Listing on the Parameters of Characteristic Lines Models, Journal of Business Finance and Accounting, vol. 16, 335-342.

Reints W. W. and P. A. Vandenberg, 1975, The Impact of Changes in Trading Location on a Security's Systematic Risk, Journal of Financial and Quantitative Analysis, vol. 10, 881-890.

Sanger G. C. and J. J. Mac Connell, 1986, Stock Exchange Listings, Firm Value, and Security Market Efficiency: the Impact of NASDAQ, Journal of Financial and Quantitative Analysis, vol. 21, 1-25.

Schleifer A., 1986, Do Demand Curves for Stocks Slope Down, Journal of Finance, vol. 41, 579-590.

Scholes M. and J. Williams, 1977, Estimating Betas from Nonsynchronous Data, Journal of Financial Economics, vol. 5, 309-327.

Solnik B., 1984, Properties of the Efficient Frontier with Short-sales Restrictions, Finance, vol. 5, 143-157.

Van Horne J. C., 1970, New Listing and their Price Behavior, Journal of Finance, vol. 25, 783-794.

Vihj A., 1994, S\&P 500 Trading Strategies and Stock Betas, Review of Financial Studies, vol. 7, $215-251$.

Woolridge J.R. and C. Ghosh, 1986, Institutional Trading and Security Prices: The Case of Changes in the Composition of the S\&P 500 Index, Journal of Financial Research, vol. 9, 13-24.

Ying L. K., W. G. Lewellen, G. G. Schlarbaum and R. C Lease, 1977, Stock Exchange Listing and Securities Returns, Journal of Financial and Quantitative Analysis, vol. 12, 415-432. 